\title{
Laju Sedimentasi di Dataran Banjir Sungai Ciujung Hulu Berdasarkan Profil Pb-210 Excess
}

\section{Sedimentation Rate in Ciujung Hulu River Floodplain Based on Pb-210 Excess Profile}

\author{
Barokah Aliyanta*, Nita Suhartini \\ PAIR-BATAN, Jl. Lebak Bulus Raya no. 49, Jakarta, Indonesia, 12440 \\ Email: barali@batan.go.id \\ Naskah diterima: 19 Maret 2018, direvisi: 24 Mei 2018, disetujui: 31 Mei 2018 \\ DOI: $\underline{10.17146 / \text { eksplorium.2018.39.1.4165 }}$
}

\begin{abstract}
ABSTRAK
Laju deposisi sedimen di dataran banjir merupakan salah satu komponen dalam budget sedimen daerah aliran sungai (DAS). Oleh karena itu, perlu dilakukan perhitungan estimasi laju deposisi sedimen di dua lokasi dataran banjir berdasarkan penanggalan umur sedimen dengan teknik $\mathrm{Pb}-210$ excess. Core sedimen diambil di dataran banjir Sungai Ciujung Hulu tiap interval kedalaman $10 \mathrm{~cm}$ sampai kedalaman $120 \mathrm{~cm}$. Sedimen yang didapat dikeringkan, diayak, ditimbang 150-300 gr, ditempatkan dalam wadah khusus dan ditutup rapat. Setelah sebulan dalam kondisi tertutup rapat, sampel diukur dengan spektrometer gamma Multichannel analyzer (MCA) untuk mengetahui aktivitas $\mathrm{Pb}-210$ total dan $\mathrm{Pb}-210$ supported. Berdasarkan data $\mathrm{Pb}-210$ total dan $\mathrm{Pb}-210$ supported, terdapat tiga cara berbeda untuk mendapatkan profil $\mathrm{Pb}-210$ excess. Data $\mathrm{Pb}-210$ excess yang diperoleh digunakan untuk menghitung umur sedimen berdasarkan metode constant of the rate of supply (CRS). Melalui umur tiap perlapisan sedimen ini, dapat diketahui adanya zona peralihan laju deposisi sedimen di kedua lokasi. Laju sedimentasi berkisar 1,028 cm/tahun dari tahun $1968 \mathrm{~s} / \mathrm{d}$ 1987, dan naik menjadi sekitar 2,83 cm/tahun dari tahun 1987-2016 (28,95 tahun) di lokasi 1. Di lokasi 2, laju sedimentasi berkisar 0,676 cm/tahun dari tahun 1950-1993, dan naik menjadi kisaran 3,231 cm/tahun dari kurun waktu tahun 1993-2016 (23 tahun).
\end{abstract}

Kata kunci: $\mathrm{Pb}-210$ excess, CRS, umur sedimen, laju sedimentasi

\begin{abstract}
The rate of deposition of sediment on the floodplain area is one of the constituent component of the sediment budget in watersheds. Therefore, the sedimentation rate estimation has been made in two locations of the floodplains based on the age sediment obtained using Pb-210 excess technique. Sediment cores were taken in the Ciujung Hulu River floodplain every $10 \mathrm{~cm}$ depth intervals up to a depth of $120 \mathrm{~cm}$. Sediment was obtained then dried, disaggregated, sifted, weighing 150-300 gr, placed into the special containers and tightly closed. After a month in a sealed condition, samples were measured using gamma spectrometer Multichannel analyzer (MCA) to find out the activity of Pb-210 total and Pb-210 supported. Based on the data of Pb-210 total and Pb-210 supported, there are three different ways to get Pb-210 excess profiles. Obtained Pb-210 excess data is used to calculate the age of the sediments on the basis of the method of constant rate of supply (CRS). Through the age of sediment layers, can be recognized the existence of transitional zone of sediment deposition rate at both locations. The rate of sedimentation ranged from $1.028 \mathrm{~cm} /$ year from the years 1968-1987, and rose to about $2.83 \mathrm{~cm} /$ year from the years 1987-2016 (28.95 years) at location 1. While in location 2, the rate of sedimentation ranged 0.676 cm/year from the years 1950-1993, and rose to about $3.231 \mathrm{~cm} /$ year from the years 1993-2016 (2 years).
\end{abstract}

Keywords: Pb-210 excess, CRS, sediment age, rate of sedimentation 


\section{PENDAHULUAN}

Sungai Ciujung merupakan sungai utama di Provinsi Banten. Sebagai sumber daya alam, sungai ini banyak dimanfaatkan untuk berbagai tujuan, antara lain penyediaan air irigasi, sarana rekreasi, usaha perikanan, dan lain lain. Sungai Ciujung terbagi dalam lima (5) sub-daerah aliran sungai (DAS), dengan sub-DAS yang ada di hulu dikenal sebagai sub-DAS Ciujung Hulu. Sejak sepuluh tahun lalu mutu air Sungai Ciujung mengalami kemerosotan akibat sedimentasi, baik di aliran sungai maupun endapan sedimen di dataran banjir/teras sungai [1].

Material sedimen yang berasal dari sumber-sumber sedimen yang terbawa oleh aliran air limpasan ketika hujan terangkut di dalam aliran Sungai Ciujung Hulu dan menyebabkan terjadinya endapan sediment bed di dasar aliran sungai dan endapan sedimen di dataran banjir yang terbentuk karena proses inundasi dari sedimen suspensi. Sumber-sumber sedimen potensial tersebut antara lain adalah erosi lahan, penambangan pasir, serta erosi parit dari lapisan sub-soil dan river bank.

Sedimen di dataran banjir ini mengandung radionuklida $\mathrm{Pb}-210$. $\mathrm{Pb}-210$ merupakan radionuklida lingkungan yang berasal dari peluruhan induk ${ }^{238} \mathrm{U}$ [2]. $\mathrm{Pb}-210$ mempunyai waktu paruh 22,3 tahun. Radionuklida $\mathrm{Pb}-210$ terdiri dari radionuklida jatuhan (fallout) yang melekat kuat pada partikel halus sedimen/tanah, disebut sebagai $\mathrm{Pb}-210$ excess/unsupported dan $\mathrm{Pb}-210$ yang bukan berasal dari jatuhan disebut sebagai $\mathrm{Pb}-210$ supported. Dalam sedimen, aktivitas $\mathrm{Pb}-210$ dapat dibedakan antara $\mathrm{Pb}-210$ excess dan $\mathrm{Pb}-210$ supported melalui pengukuran dengan peralatan multi channel analyzer secara langsung dari radiasi gamma yang dipancarkan menggunakan detektor low energy $[3,4]$.

Ditinjau dari sumbernya, sedimen di dataran banjir ini umumnya akan banyak mengandung $\mathrm{Pb}-210$ excess jika berasal dari tanah permukaan yang tererosi akibat aktivitas pertanian [5] atau akan mengandung sangat sedikit atau bahkan tidak mengandung sama sekali $\mathrm{Pb}-210$ excess bila partikel halusnya dominan berasal dari river bank, erosi parit, atau berasal dari cucian penambangan pasir. Dengan asumsi pada tempat perlapisan sedimen di dataran banjir tidak mengalami gangguan, maka besar kecilnya aktivitas $\mathrm{Pb}-210$ excess pada perlapisan sedimen disebabkan oleh adanya perbedaan proporsi percampuran berbagai sumber potensial tersebut serta faktor peluruhan radioaktif. Dengan asumsi demikian, teknik radionuklida $\mathrm{Pb}-210$ excess dapat dijadikan sebagai sarana untuk melakukan berbagai kajian, seperti estimasi laju sedimentasi dataran banjir [6,7], identifikasi dan penentuan daerah sumber sedimen [8], maupun untuk mengetahui perluasan area sedimentasi dataran banjir antara aliran air yang dikendalikan dengan tidak dikendalikan [9].

Dalam rangka untuk membantu menyediakan salah satu komponen data dalam menyusun model sediment budget subDAS/DAS yang berperan dalam pengelolaan sub-DAS/DAS terintegrasi, diperlukan data estimasi laju sedimentasi di dataran banjir. Untuk itu, perlu dilakukan penanggalan umur sedimen dengan teknik penanggalan radioaktif (dating) $\mathrm{Pb}-210$ excess untuk estimasi laju sedimentasi. Dua asumsi penting diperlukan untuk penanggalan umur sedimen, yaitu jatuhan radionuklida $\mathrm{Pb}-210$ excess di seluruh kawasan sub-DAS Ciujung Hulu, dan $\mathrm{Pb}-210$ excess yang terukur pada tiap interval 
sedimen di dataran banjir yang merupakan hasil dari pengendapan proses inundasi dari berbagai sumber potensial yang ada. Melalui pengambilan sampel dengan alat core pada lokasi endapan sedimen di dataran banjir dan pengukuran aktivitas $\mathrm{Pb}-210$ total dan $\mathrm{Pb}-210$ supported akan diperoleh profil aktivitas ${ }^{210} \mathrm{~Pb}$ excess dalam keseluruhan kolom sedimen. Dengan demikian maka laju deposisi sedimen/laju sedimentasi di dataran banjir dapat diestimasi. Data estimasi laju sedimentasi daratan banjir ini akan melengkapi data lain seperti laju erosi, kontribusi sumber erosi, dan data sedimen yield ke dalam model konstruksi sedimen budget sub-DAS Ciujung Hulu.

\section{BAHAN DAN METODE}

\section{Lokasi Pengambilan Sampel}

Lokasi pengambilan sampel endapan sedimen dataran banjir/teras sungai terletak di daerah aliran Sungai Ciujung Hulu seperti dapat dilihat pada Gambar 1. Pengambilan sampel endapan sedimen dilakukan dengan alat core sedimen berdiameter dalam $7 \mathrm{~cm}$ dan dilengkapi dengan tangkai sepanjang 130 $\mathrm{cm}$. Sedimen diambil secara bertahap dengan interval kedalaman $10 \mathrm{~cm}$. Sedimen dikeluarkan dari core dan ditaruh di dalam kantong contoh dan diberikan label sesuai dengan interval kedalamannya. Pengambilan sampel dilakukan setiap interval kedalaman $10 \mathrm{~cm}$ sampai kedalaman $120 \mathrm{~cm}$.

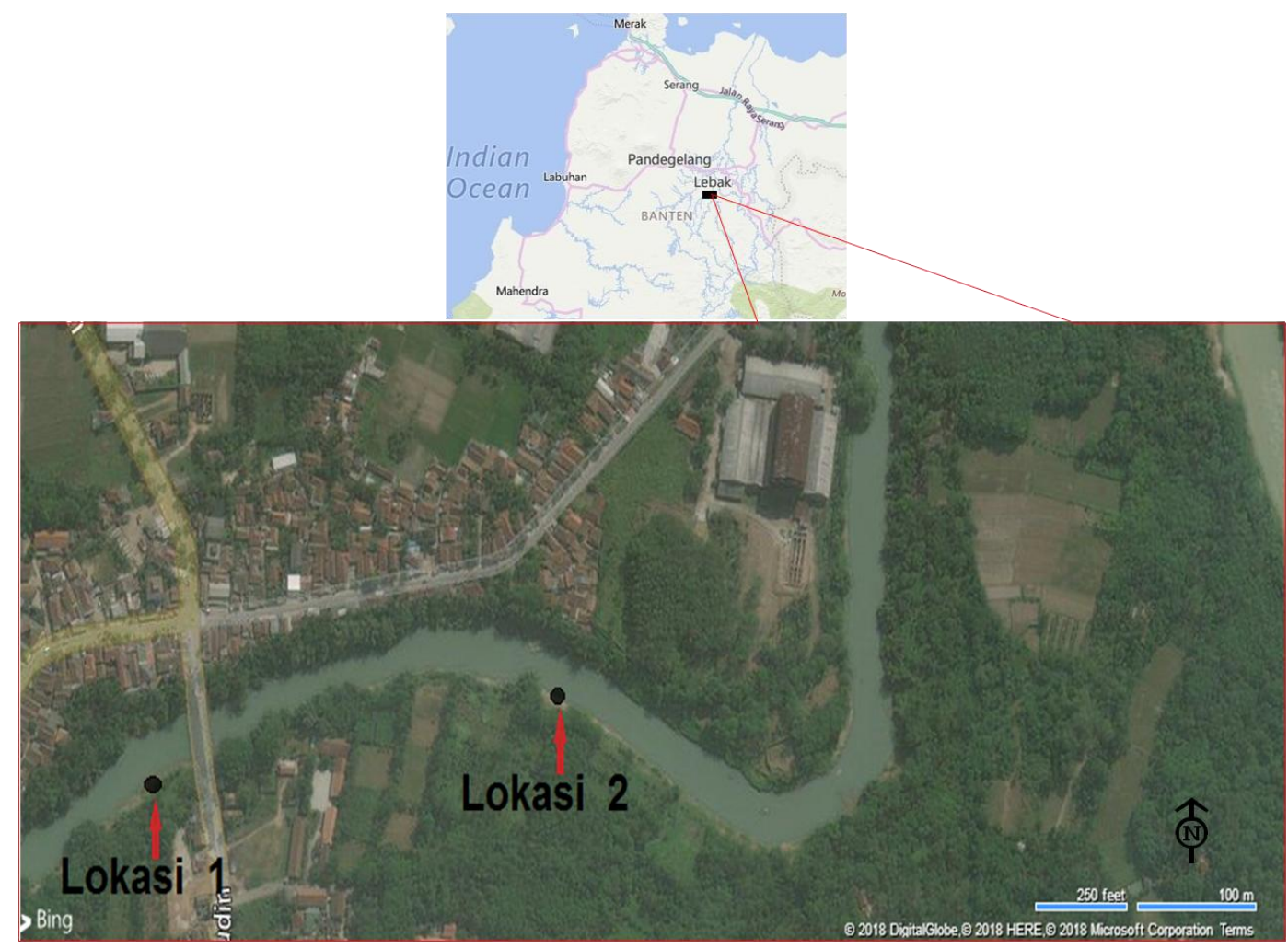

Gambar 1. Pengambilan sampel sedimen di dataran banjir (sumber: googlemaps).

Preparasi Sampel dan Pengukuran Dengan Multi Channel Analizer (MCA)

Sampel sedimen yang telah diambil tiap interval kedalaman $10 \mathrm{~cm}$ ini dipreparasi di laboratorium dengan diangin-anginkan selama 48 jam. Sampel dipanaskan dengan oven pada suhu $60^{\circ} \mathrm{C}$ selama 2 hari. Sampel yang telah kering tersebut digerus untuk memisahkan butirannya, diayak dengan ayakan bermesh $1 \mathrm{~mm}$, ditimbang antara 
150-300 gr (tergantung perolehan sampelnya) dan ditempatkan di tabung merrineli, lalu ditutup rapat dan dibiarkan kurang lebih 1 bulan agar tercapai keseimbangan antara Ra226 dan anak luruhnya $\mathrm{Pb}-210$. Setelah sebulan dalam kondisi tertutup rapat, sampel diukur dengan spektrometer gamma Multichannel analyzer (MCA) [10]. Masingmasing sampel diukur aktivitas $\mathrm{Pb}-210$ excess melalui pengukuran aktivitas gamma pada energi sekitar $46,5 \mathrm{KeV}$ sebagai representasi $\mathrm{Pb}-210$ total dan pada energi $351 \mathrm{KeV}$ (Bi214) [11] sebagai representasi $\mathrm{Pb}-210$ supported menggunakan alat spektrometer gamma MCA dengan relatif efisiensi 30\% dalam laboratorium cacah latar rendah milik Pusat Aplikasi Isotop dan Radiasi-Badan Tenaga Nuklir Nasional (PAIR-BATAN).

\section{Pengukuran Kandungan Organik Karbon}

Setelah selesai dilakukan pengukuran dengan MCA, sampel dibuka dan diambil sekitar 10 gram kemudian dipanaskan dengan oven sampai suhu $110^{\circ} \mathrm{C}$. Selanjutnya, sampel didinginkan dan ditimbang kembali. Sampel yang telah ditimbang kembali tersebut kemudian dipanaskan dalam furnace pada suhu $450^{\circ} \mathrm{C}$ selama 3 jam, didinginkan, dan ditimbang kembali. Selisih dari berat timbangan setelah dipanaskan dalam furnace merupakan Total Organik Material (TOM) yang terbakar/hilang. Pengukuran TOM dilakukan pada setiap interval kedalaman untuk menormalisasi aktivitas $\mathrm{Pb}-210$ excess terhadap kandungan organik karbonnya. Persentase Total Organik Karbon (TOC) dihitung dengan asumsi sama dengan 0,47 TOM [12].

\section{Analisis Data}

Data profil dari $\mathrm{Pb}-210$ excess tiap kolom sedimen di dataran banjir diperoleh dengan tiga cara berbeda untuk mengestimasi umur lapisan sedimennya dengan model constant rate of supply (CRS). Cara pertama adalah profil $\mathrm{Pb}-210$ excess diperoleh dengan mengurangkan aktivitas $\mathrm{Pb}-210$ total dengan $\mathrm{Pb}-210$ supported pada masing-masing interval kedalaman. Cara kedua adalah profil $\mathrm{Pb}-210$ excess diperoleh dengan mengurangi aktivitas $\mathrm{Pb}-210$ total tiap interval kedalaman dengan $\mathrm{Pb}-210$ supported rata-rata seluruh kolom sedimen. Cara ketiga adalah mengacu pada hasil penelitian terdahulu, bahwa $\mathrm{Pb}-210$ excess dan soil organik karbon (SOC) bergerak bersama selama proses erosi lahan $[13,14]$, maka profil $\mathrm{Pb}-210$ excess diperoleh dengan mengurangi aktivitas $\mathrm{Pb}-210$ total tiap interval kedalaman dengan $\mathrm{Pb}-210$ supported yang dinormalisasi terhadap kandungan ratarata persentase organik karbon. Dari profil tersebut diestimasi umur tiap lapisan sedimen dengan model CRS [15]. Perhitungan umur sedimen dengan model CRS didasarkan pada peluruhan radioaktif berikut:

$$
\begin{aligned}
& \mathrm{Az}=\mathrm{A}(0) \mathrm{e}^{-\lambda \mathrm{t}} \rightarrow \frac{A z}{A(0)}=\mathrm{e}^{-\lambda \mathrm{t}} \\
& \rightarrow \ln \left(\frac{A z}{A(0)}\right)=-\lambda \mathrm{t} \rightarrow \ln \left(\frac{A(0)}{A z}\right)=\lambda \mathrm{t} \\
& \text { Atau } \rightarrow \mathrm{t}=\frac{1}{\lambda} \ln \frac{A(0)}{A z}
\end{aligned}
$$

dengan $\mathrm{A}(0)$ adalah total inventori $\mathrm{Pb}-210$ excess $\left(\mathrm{Bq} / \mathrm{m}^{2}\right)$ dari lapisan sedimen paling atas sampai paling bawah (keseluruhan kolom sedimen); $\mathrm{Az}$ adalah inventori $\mathrm{Pb}-210$ excess di bawah kedalaman $\mathrm{z} ; \lambda$ adalah tetapan peluruhan $\mathrm{Pb}-210$.

Laju deposisi sedimen atau laju sedimentasi pada tiap satuan waktu dihitung dengan pendekatan menggunakan persamaan regresi antara kedalaman sedimen dengan umur sebagai berikut:

$$
\mathrm{R}=\mathrm{m} \mathrm{t}+\mathrm{A}
$$

dengan $\mathrm{R}$ adalah kedalaman sedimen $(\mathrm{cm}) ; \mathrm{m}$ adalah laju deposisi sedimen bulk (cm/tahun) 
atau laju sedimentasi; $\mathrm{t}$ adalah umur sedimen (tahun); dan A adalah konstanta.

\section{HASIL DAN PEMBAHASAN}

\section{Hasil Pengukuran Radionuklida dan TOM}

Hasil pengukuran aktivitas $\mathrm{Pb}-210$ excess melalui $\mathrm{Pb}-210$ total dan $\mathrm{Pb}-210$ supported serta TOM dari keseluruhan interval kedalaman sedimen di lokasi 1 dan 2 dapat dilihat pada Tabel 1 dan Tabel 2, sedangkan profil $\mathrm{Pb}-210$ total dan $\mathrm{Pb}-210$ supported terhadap kedalaman dapat dilihat pada Gambar 2 dan Gambar 3. Pada lokasi 1 nampak bahwa aktivitas $\mathrm{Pb}-210$ total sangat fluktuatif, mempunyai aktivitas berkisar dari $22-76 \mathrm{~Bq} / \mathrm{kg}$ dengan aktivitas tertinggi, yaitu $76,8 \mathrm{~Bq} / \mathrm{kg}$ berada di lapisan sedimen paling atas dan aktivitas terendah, yaitu $22,47 \mathrm{~Bq} / \mathrm{kg}$ berada pada lapisan interval kedalaman 40-50 cm (Tabel 1 dan Gambar 2). Aktivitas Pb-210 supported juga bervariasi dengan kisaran 10 $33 \mathrm{~Bq} / \mathrm{kg}$ dengan aktivitas $\mathrm{Pb}-210$ supported tertinggi adalah $33,27 \mathrm{~Bq} / \mathrm{kg}$ yang berada pada lapisan 90-100 cm dan aktivitas terendah adalah $10,26 \mathrm{~Bq} / \mathrm{kg}$ yang berada pada lapisan interval kedalaman 100-110 cm (Tabel 1). Kandungan total organik material (TOM) juga bervariasi dari kisaran 6-17\%, dengan nilai terendah adalah $6,45 \%$ pada interval kedalaman 110-120 dan tertinggi adalah $17,12 \%$ pada interval kedalaman $0-10$ $\mathrm{cm}$ (Tabel 1). Hubungan yang signifikan antara aktivitas $\mathrm{Pb}-210$ total dengan TOM (dengan koefisisien determinasi $r^{2}=0,11$ ) tidak ditemukan dengan menggunakan regresi linear biasa. Secara umum, aktivitas $\mathrm{Pb}-210$ total dan kandungan TOM tidak ada saling ketergantungan. Hal demikian tentunya dapat dimengerti mengingat bahwa sedimen yang terdeposisi di dataran banjir tersebut memang mempunyai sumber potensial yang cukup beragam dengan kandungan organik material yang bervariasi. Demikian juga dengan aktivitas $\mathrm{Pb}-210$ total yang merupakan gabungan dari komponen sumber potensial yang ada.

Bila sedimen di dataran banjir didominasi oleh erosi lembaran dari lahan, baik kualitas maupun kuantitasnya maka kemungkinan aktivitas $\mathrm{Pb}-210$ totalnya juga akan tinggi. Sebaliknya, bila sumber utama dari sedimen didominasi oleh sedimen dari lapisan sub-soil atau erosi river bank maka aktivitas $\mathrm{Pb}-210$ total juga relatif kecil, dan seterusnya. Begitu juga halnya terhadap kandungan TOM.

Tabel 1. Hasil pengukuran aktivitas $\mathrm{Pb}-210$ dan parameter lain di lokasi 1.

\begin{tabular}{cccccc}
\hline $\begin{array}{c}\text { Kedalaman } \\
(\mathbf{c m})\end{array}$ & $\begin{array}{c}\mathbf{P b - 2 1 0} \text { total } \\
(\mathbf{B q} / \mathbf{k g})\end{array}$ & $\begin{array}{c}\mathbf{P b - 2 1 0} \\
\mathbf{s u p p o r t e d} \\
\mathbf{( B q} / \mathbf{k g})\end{array}$ & $\begin{array}{c}\mathbf{D W} \\
\mathbf{( k g )}\end{array}$ & $\begin{array}{c}\text { TOM } \\
(\boldsymbol{\%})\end{array}$ & $\begin{array}{c}\text { TOC } \\
(\boldsymbol{\%})\end{array}$ \\
\hline $0-10)$ & 76,83 & 22,02 & 0,34 & 17,12 & 8,05 \\
$(10-20$ & 71,49 & 17,40 & 0,38 & 12,72 & 5,98 \\
$20-30$ & 24,75 & 15,19 & 0,42 & 9,93 & 4,67 \\
$30-40$ & 49,06 & 26,08 & 0,27 & 12,83 & 6,03 \\
$40-50$ & 22,47 & 18,54 & 0,194 & 14,21 & 6,68 \\
$50-60$ & 23,57 & 14,21 & 0,224 & 16,68 & 7,84 \\
$60-70$ & 54,03 & 17,94 & 0,323 & 13,19 & 6,20 \\
$70-80$ & 31,28 & 27,11 & 0,215 & 15,17 & 7,13 \\
$80-90$ & 69,65 & 23,63 & 0,256 & 16,01 & 7,52 \\
$90-100$ & 67,73 & 33,27 & 0,191 & 13,84 & 6,50 \\
$100-110$ & 47,37 & 10,26 & 0,421 & 11,66 & 5,48 \\
$110-120$ & 30,74 & 16,43 & 0,541 & 6,45 & 3,03 \\
\hline
\end{tabular}


Tabel 2. Hasil pengukuran aktivitas Pb-210 dan parameter lain di lokasi 2.

\begin{tabular}{cccccc}
\hline $\begin{array}{c}\text { Kedalaman } \\
(\mathbf{c m})\end{array}$ & $\begin{array}{c}\mathbf{P b - 2 1 0} \text { total } \\
(\mathbf{B q} / \mathbf{k g})\end{array}$ & $\begin{array}{c}\text { Pb-210 } \\
\text { supported } \\
(\mathbf{B q} / \mathbf{k g})\end{array}$ & $\begin{array}{c}\mathbf{D W} \\
\mathbf{( k g})\end{array}$ & $\begin{array}{c}\text { TOM } \\
(\boldsymbol{\%})\end{array}$ & $\begin{array}{c}\text { TOC } \\
(\boldsymbol{\%})\end{array}$ \\
\hline $0-10$ & 24,07 & 14,59 & 0,287 & 19,42 & 9,13 \\
$10-20$ & 80,55 & 25,19 & 0,302 & 16,71 & 7,85 \\
$20-30$ & 53,57 & 17,20 & 0,372 & 15,76 & 7,41 \\
$30-40$ & 60,31 & 14,67 & 0,441 & 15,72 & 7,39 \\
$40-50$ & 36,08 & 16,74 & 0,398 & 15,15 & 7,12 \\
$50-60$ & 19,64 & 19,15 & 0,353 & 15,23 & 7,16 \\
$60-70$ & 46,33 & 13,79 & 0,449 & 16,08 & 7,56 \\
$70-80$ & 43,97 & 25,76 & 0,344 & 15,53 & 7,30 \\
$80-90$ & 58,91 & 14,54 & 0,550 & 14,55 & 6,84 \\
$90-100$ & 54,73 & 17,83 & 0,556 & 17,33 & 8,15 \\
$100-110$ & 32,85 & 15,26 & 0,734 & 16,00 & 7,52 \\
$110-120$ & 55,66 & 20,79 & 0,575 & 16,11 & 7,57 \\
\hline
\end{tabular}

Aktivitas $\mathrm{Pb}-210$ total di lokasi 2 juga berfluktuasi dan mempunyai aktivitas berkisar antara $19-80 \mathrm{~Bq} / \mathrm{kg}$ dengan aktivitas tertinggi, yaitu $80,55 \mathrm{~Bq} / \mathrm{kg}$ berada di lapisan interval kedalaman 10-20 cm dan aktivitas terendah, yaitu $19,64 \mathrm{~Bq} / \mathrm{kg}$ berada pada lapisan interval kedalaman 50-60 cm (Tabel 2 dan Gambar 3). Ternyata antara kolom sedimen di lokasi 1 dan 2 juga mempunyai perbedaan profil $\mathrm{Pb}-210$ total. Aktivitas $\mathrm{Pb}-$ 210 supported juga bervariasi dengan kisaran 13-25 Bq/kg dengan aktivitas $\mathrm{Pb}-210$ supported tertinggi adalah 25,76 Bq/kg berada pada lapisan $70-80 \mathrm{~cm}$ dan aktivitas terendah adalah $13,79 \mathrm{~Bq} / \mathrm{kg}$ berada pada lapisan interval kedalaman 60-70 cm (Tabel 2).
Sedimen di lokasi 2 pun tidak memiliki hubungan yang signifikan antara $\mathrm{Pb}-210$ total dengan kandungan TOM $\left(\mathrm{r}^{2}=0,02\right)$. Hal ini juga disebabkan oleh proses kejadian yang sama pada lokasi 1, yaitu banyaknya kemungkinan kombinasi proporsionalitas sumber potensial penyusun sedimen.

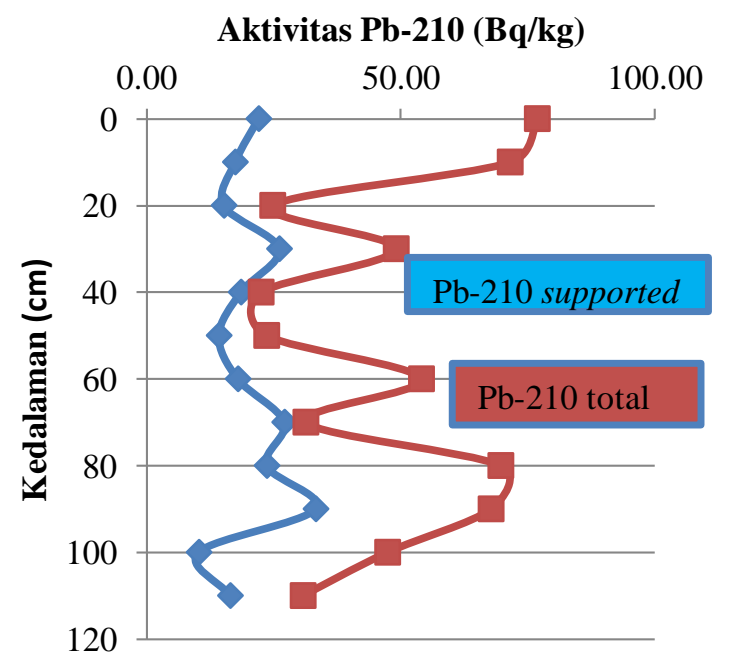

Gambar 2. Profil Pb-210 total dan Pb-210 supported terhadap kedalaman di lokasi 1. 


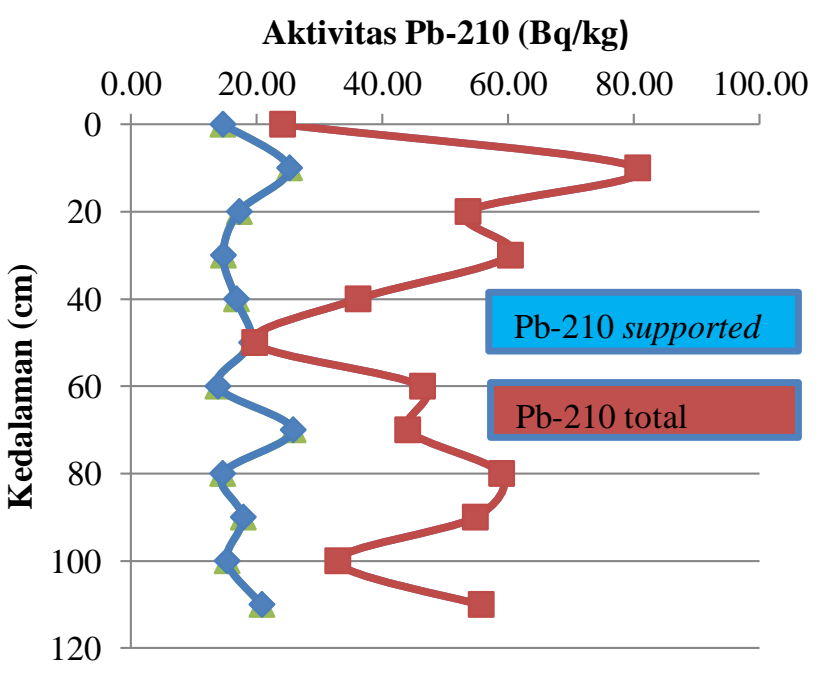

Gambar 3. Profil $\mathrm{Pb}-210$ total dan $\mathrm{Pb}-210$ supported terhadap kedalaman di lokasi 2.

\section{Aktivitas Pb-210 excess dan Estimasi Umur Sedimen}

Profil $\mathrm{Pb}-210$ excess diperoleh dengan tiga cara berbeda, yaitu aktivitas $\mathrm{Pb}-210$ total dikurangi dengan $\mathrm{Pb}-210$ supported pada masing-masing interval kedalaman; aktivitas $\mathrm{Pb}-210$ total dikurangi dengan $\mathrm{Pb}-210$ supported rata-rata seluruh kolom sedimen; dan aktivitas $\mathrm{Pb}-210$ total dikurangi dengan $\mathrm{Pb}-210$ supported tiap interval kedalaman yang dinormalisasi terhadap rata-rata persentase organik karbon (\%C). Hasil ketiga cara ini dapat dilihat pada Tabel 3 pada kolom 2, 3, dan 4 sedangkan perhitungan estimasi umurnya dapat dilihat pada Tabel yang sama pada kolom 5, 6, dan 7. Secara umum, ada kecenderungan yang serupa dari kurva antara kedalaman sedimen dan estimasi umur sedimen seperti yang terlihat pada Gambar 4 dan Gambar 5.

\section{Pb-210 excess di Lokasi 1 dan Umur Sedimen}

$\mathrm{Pb}-210$ excess pada kolom sedimen dataran banjir di lokasi 1 seperti dapat dilihat pada Tabel 3 mempunyai nilai positif semua.
Aktivitas $\mathrm{Pb}-210$ excess merupakan deposisi dari sedimen suspensi dan merupakan percampuran berbagai sumber sedimen potensial seperti lahan tererosi yang berupa erosi lembaran, dari hasil cucian pasir maupun dari erosi parit/lapisan sub-soil dan erosi river bank. Nilai positif $\mathrm{Pb}-210$ excess dari sedimen di dataran banjir tersebut menunjukkan bahwa sedimen yang berasal dari erosi lembaran mendominasi sumber sedimen potensial. Semakin tinggi aktivitas $\mathrm{Pb}-210$ excess mengindikasikan semakin tingginya kontribusi dari erosi lembaran lahan pertanian dan begitu pula sebaliknya. Profil aktivitas $\mathrm{Pb}-210$ excess di lokasi 1 berfluktuasi terhadap kedalaman. Aktivitas $\mathrm{Pb}-210$ excess tertinggi terlihat pada lapisan permukaan dengan aktivitas $54,80 \mathrm{~Bq} / \mathrm{kg}$ dan aktivitas terendah ada pada lapisan interval kedalaman 40-50 cm dengan aktivitas 3,93 $\mathrm{Bq} / \mathrm{kq}$. Idealnya, aktivitas tertinggi berada pada lapisan sedimen paling atas dan apabila jumlah sumber sedimen dan faktor luar yang mempengaruhi relatif sama, aktivitas $\mathrm{Pb}-210$ excess akan semakin kecil ke arah semakin ke dalam secara eksponensial [4]. Fluktuasi aktivitas $\mathrm{Pb}-210$ excess yang diperoleh dengan cara kesatu tersebut juga sama dengan profil $\mathrm{Pb}-210$ excess yang diperoleh dengan cara kedua maupun cara ketiga.

Dengan cara kedua, aktivitas $\mathrm{Pb}-210$ excess tertinggi berada lapisan permukaan, yaitu 56,66 Bq/kg dan aktivitas terendah berada pada interval kedalaman $40-50 \mathrm{~cm}$, yaitu $2,30 \mathrm{~Bq} / \mathrm{kg}$. Demikian juga dengan cara ketiga, diperoleh aktivitas $\mathrm{Pb}-210$ excess tertinggi berada lapisan permukaan, yaitu $70,46 \mathrm{~Bq} / \mathrm{kg}$ dan aktivitas terendah berada pada interval kedalaman $40-50 \mathrm{~cm}$, yaitu 4,20 $\mathrm{Bq} / \mathrm{kg}$. 
Tabel 3. Hasil estimasi umur lapisan sedimen lokasi 1.

\begin{tabular}{cccccc}
\hline Cara-1 & $\begin{array}{c}\text { Pb-210 excess } \mathbf{( B q} / \mathbf{k g}) \\
\text { Cara-2 }\end{array}$ & Cara-3 & \multicolumn{3}{c}{ Umur Tiap Perlapisan Sedimen (th) } \\
Cara-1 & Cara-2 & Cara-3 \\
\hline 54,80 & 56,66 & 70,45 & 0,00 & 0,00 & 0,00 \\
54,08 & 51,32 & 51,66 & 6,12 & 6,74 & 8,07 \\
9,56 & 4,58 & 7,13 & 14,72 & 15,54 & 16,78 \\
22,97 & 28,89 & 22,13 & 16,71 & 16,55 & 18,35 \\
3,93 & 2,30 & 4,20 & 19,97 & 20,93 & 21,65 \\
9,36 & 3,40 & 11,72 & 20,40 & 21,21 & 22,13 \\
36,09 & 33,86 & 35,74 & 21,62 & 21,68 & 23,74 \\
4,17 & 11,11 & 4,75 & 29,38 & 29,37 & 31,98 \\
46,02 & 46,02 & 55,32 & 30,07 & 31,33 & 32,83 \\
34,46 & 47,56 & 35,81 & 40,72 & 43,23 & 47,59 \\
37,11 & 27,20 & 32,49 & 48,69 & 56,87 & 58,22 \\
14,31 & 10,57 & 6,93 & 84,16 & 92,17 & 107,56 \\
\hline
\end{tabular}

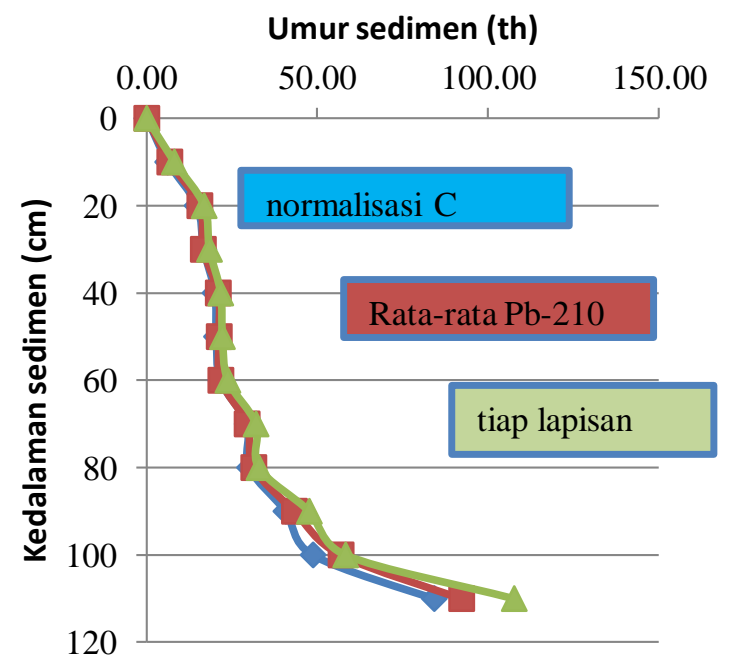

Gambar 4. Umur sedimen tiap kedalaman di lokasi 1.

Perhitungan estimasi umur tiap perlapisan sedimen memerlukan aktivitas $\mathrm{Pb}$ 210 excess dari keseluruhan kolom sedimen yang diperoleh dengan menggunakan model CRS yang ditulis dalam persamaan (1). Hasil perhitungan estimasi umur sedimen lokasi 1 dapat dilihat pada Tabel 3 pada kolom 4, 5, dan 6. Berdasarkan persamaan (1), sedimen paling atas/permukaan (kedalaman $0 \mathrm{~cm}$ ) berumur 0 tahun, yaitu umur sampel sedimen diambil (tahun 2016 bulan Agustus). Umur sedimen yang dihitung melalui interval kedalaman merupakan umur sedimen pada kedalaman dengan batas interval atas, misal pada interval kedalaman sedimen $10-20 \mathrm{~cm}$ berarti umur sedimen yang terukur pada kedalaman $10 \mathrm{~cm}$ dan seterusnya. Hasil perhitungan estimasi umur sedimen dengan ketiga cara penentuan $\mathrm{Pb}-210$ excess juga dapat dilihat pada Gambar 4. Untuk memudahkan dalam analisis pada Gambar 4, hasil estimasi umur sedimen dari profil $\mathrm{Pb}$ 210 excess melalui pengurangan aktivitas $\mathrm{Pb}$ 210 total dikurangi dengan $\mathrm{Pb}-210$ supported pada masing-masing interval kedalaman yang dinotasikan dengan tiap lapisan; aktivitas $\mathrm{Pb}$ 210 total dikurangi dengan $\mathrm{Pb}-210$ supported rata-rata seluruh kolom sedimen dinotasikan dengan rata-rata $\mathrm{Pb}-210$; dan aktivitas $\mathrm{Pb}-210$ total dikurangi dengan $\mathrm{Pb}-210$ supported tiap interval kedalaman yang dinormalisasi terhadap rata-rata persentase organik karbon (\% C) dinotasikan dengan normalisasi $\mathrm{C}$. Melalui ketiga cara di atas, umur sedimen yang diperoleh tidak berbeda signifikan, khususnya pada kedalaman kurang dari 90 $\mathrm{cm}$. Secara umum hasil perhitungan umur yang lebih mendekati adalah melalui perolehan $\mathrm{Pb}-210$ excess dari pengurangan langsung $\mathrm{Pb}-210$ total dengan $\mathrm{Pb}-210$ supported tiap lapisan sedimen. Profil $\mathrm{Pb}-210$ excess diperoleh dari pengurangan aktivitas $\mathrm{Pb}-210$ total tiap interval kedalaman terhadap 
$\mathrm{Pb}-210$ supported yang dinormalisasi terhadap kandungan rata-rata persentase organik karbon.

\section{Pb-210 excess di Lokasi 2 dan Umur Sedimen}

Aktivitas $\mathrm{Pb}-210$ excess kolom sedimen dataran banjir di lokasi 2 seperti dapat dilihat pada Tabel 4 kolom 2, 3, dan 4 mempunyai nilai positif semua. Proses kejadian pengendapan sedimen di lokasi 2 serupa dengan di lokasi 1 meskipun lokasi 2 berada lebih ke arah hilir dibandingkan lokasi 1. Secara profil, aktivitas $\mathrm{Pb}-210$ excess di lokasi 2 berfluktuasi terhadap kedalaman. Aktivitas $\mathrm{Pb}-210$ excess tertinggi terlihat pada lapisan dengan interval kedalaman 10-20 cm, yaitu $55,36 \mathrm{~Bq} / \mathrm{kg}$ dan aktivitas terendah ada pada lapisan interval kedalaman $50-60 \mathrm{~cm}$ dengan aktivitas $0,49 \mathrm{~Bq} / \mathrm{kq}$. Fluktuasi aktivitas $\mathrm{Pb}-210$ excess yang diperoleh dengan cara pertama juga serupa dengan profil aktivitas $\mathrm{Pb}-210$ excess yang diperoleh dengan cara kedua maupun cara ketiga. Aktivitas terbesar dan terkecil tetap berada di lapisan interval kedalaman yang sama. Dengan cara kedua, aktivitas $\mathrm{Pb}-210$ excess tertinggi berada di lapisan kedalaman 10-20 $\mathrm{cm}$, yaitu $62,59 \mathrm{~Bq} / \mathrm{kg}$ dan aktivitas terendah berada pada interval kedalaman $50-60 \mathrm{~cm}$, yaitu $1,68 \mathrm{~Bq} / \mathrm{kg}$. Demikian juga dengan cara ketiga, diperoleh aktivitas $\mathrm{Pb}-210$ excess tertinggi berada di lapisan kedalaman 10-20 $\mathrm{cm}$, yaitu $57,34 \mathrm{~Bq} / \mathrm{kg}$ dan aktivitas terendah berada pada interval kedalaman $50-60 \mathrm{~cm}$, yaitu $0,46 \mathrm{~Bq} / \mathrm{kg}$.

Dengan cara yang sama pada lokasi 1, hasil perhitungan estimasi umur sedimen lokasi 2 dapat dilihat pada Tabel 4 pada kolom 4, 5, dan 6. Umur sedimen yang dihitung melalui interval kedalaman merupakan umur sedimen pada kedalaman dengan batas interval atas, misal pada interval kedalaman sedimen $0-10 \mathrm{~cm}$ berarti umur sedimen yang terukur pada kedalaman $0 \mathrm{~cm}$ dan seterusnya. Grafik hubungan antar kedalaman dan umur sedimen dari ketiga cara penentuan $\mathrm{Pb}-210$ excess juga dapat dilihat pada Gambar 5.

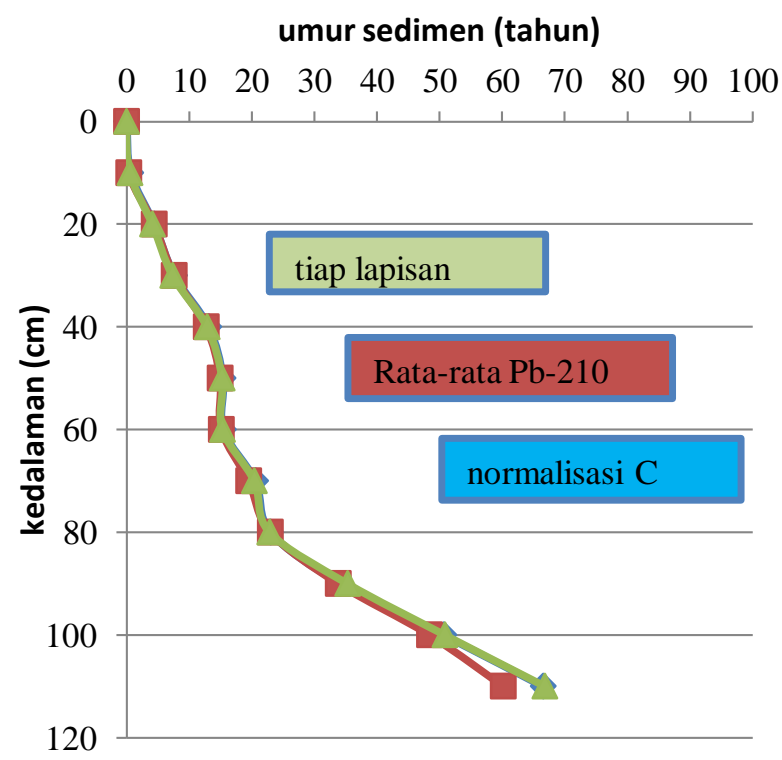

Gambar 5. Umur sedimen tiap kedalaman di lokasi 2.

Estimasi umur yang diperoleh dari cara pertama (tiap perlapisan) dengan cara ketiga (normalisasi C) sangat mendekati, bahkan pada lokasi 2 sampai pada lapisan sedimen terbawah (Tabel 4 dan Gambar 5). Pada lokasi 2, estimasi umur hanya berbeda signifikan pada kedalaman $110 \mathrm{~cm}$ dengan cara kedua, yaitu rata-rata $\mathrm{Pb}-210$. Berdasarkan pada Tabel 3, Tabel 4, Gambar 4, dan Gambar 5 dapat dikatakan bahwa perhitungan estimasi umur sedimen dengan menggunakan cara pertama atau tiap lapisan dengan cara ketiga, yaitu normalisasi C memberikan hasil yang relatif sama. Hasil umur sedimen dari dataran banjir di lokasi 2 dengan ketiga cara tersebut memberikan hasil yang lebih mendekati dibandingkan dengan lokasi 1 meskipun pada kedalaman paling bawah memberikan hasil estimasi yang juga berbeda cukup signifikan. 
Tabel 4. Hasil estimasi umur lapisan sedimen lokasi 2.

\begin{tabular}{cccccc}
\hline Cara-1 & $\begin{array}{c}\text { Pb-210 excess } \mathbf{( B q} / \mathbf{k g}) \\
\text { Cara-2 }\end{array}$ & Cara-3 & Umur Tiap Perlapisan Sedimen (th) \\
Cara-1 & Cara-2 & Cara-3 \\
\hline 9,48 & 6,11 & 11,41 & 0,00 & 0,00 & 0,00 \\
55,36 & 62,59 & 57,34 & 0,55 & 0,35 & 0,67 \\
36,37 & 35,61 & 35,53 & 4,14 & 4,42 & 4,45 \\
45,64 & 42,35 & 44,47 & 7,38 & 7,61 & 7,67 \\
19,34 & 18,12 & 18,16 & 12,89 & 12,73 & 13,14 \\
0,49 & 1,68 & 0,46 & 15,27 & 14,95 & 15,41 \\
32,54 & 28,37 & 32,43 & 15,33 & 15,14 & 15,47 \\
18,21 & 26,01 & 17,53 & 20,42 & 19,51 & 20,62 \\
46,02 & 40,95 & 41,51 & 22,88 & 22,97 & 23,02 \\
36,9 & 36,77 & 39,64 & 35,32 & 33,82 & 34,19 \\
17,59 & 14,89 & 17,45 & 50,86 & 48,40 & 50,68 \\
34,87 & 37,70 & 34,82 & 66,82 & 60,18 & 66,56 \\
\hline
\end{tabular}

\section{Laju Sedimentasi di Lokasi 1 dan 2}

Laju sedimentasi di dataran banjir dihitung dengan menggunakan persamaan (2) dari titik-titik yang berkorelasi signifikan berdasarkan dari data Tabel 3 untuk lokasi 1 dan data Tabel 4 untuk lokasi 2. Secara umum terlihat dari Gambar 4 dan Gambar 5 adanya kecenderungan kenaikan laju sedimentasi yang ditunjukkan oleh perubahan kemiringan slope antara kedalaman dan umur sedimen. Gambar 4 dan Gambar 5 digunakan untuk mempermudah melihat adanya kecenderungan perubahan laju sedimentasi melalui gradien garis penghubung antara umur dan kedalaman sedimen. Jumlah titik data yang digunakan untuk perhitungan laju sedimentasi adalah data yang diperoleh dari profil $\mathrm{Pb}-210$ excess dari cara pertama, dimana estimasi umur sedimen diperoleh melalui profil $\mathrm{Pb}-210$ excess dari pengukuran langsung. Dari kriteria tersebut, diambil titik data kedalaman 0-80 $\mathrm{cm}$ dan dari $80-100 \mathrm{~cm}$ untuk lokasi 1. Laju sedimentasi dataran banjir di lokasi 1 yang terletak di kampung Kedung Agung, Kecamatan Kalanganyar berkisar 2,83 cm/tahun dengan koefisien determinasi $r^{2}=0,914$ dan berasal dari kedalaman sedimen $0-80 \mathrm{~cm}$ atau yang diestimasikan terjadi dari tahun 1987-2016
(28,95 tahun). Laju sedimentasi dari sedimen di kedalaman 80-100 cm berkisar 1,028 $\mathrm{cm} /$ tahun dengan koefisien determinasi $\mathrm{r}^{2}=$ 0,986 atau yang diestimasikan terjadi dari tahun 1968-1987 (19 tahun). Sejak tahun 1987 sampai sekarang rata-rata laju sedimentasinya lebih dari 2,5 kali dibandingkan periode sebelum tahun 1987. Dengan cara yang sama, untuk lokasi 2 yang terletak di kampung Cilangkap, Kecamatan Kalanganyar, diperoleh pendekatan perubahan laju sedimentasi dari kedalaman 0-80 $\mathrm{cm}$ berkisar $3,231 \mathrm{~cm} /$ tahun dengan koefisien determinasi $r^{2}=0,978$, atau diestimasi terjadi dari kurun waktu tahun 1993-2016 (23 tahun). Laju sedimentasi dari kedalaman $80-110$ berkisar $0,676 \mathrm{~cm} /$ tahun dengan koefisien determinasi $r^{2}=0,997$, atau yang diestimasi terjadi dari kurun waktu tahun 1950-1993. Kedua lokasi sedimen dataran banjir ini memberikan informasi yang sangat jelas bahwa telah terjadi kenaikan laju sedimentasi yang signifikan sejak tahun 1987 .

\section{KESIMPULAN}

Sampel sedimen di dataran banjir berasal dari pengendapan sedimen suspensi yang berasal dari berbagai sumber potensial. Sedimentasi di dataran banjir senantiasa 
berulang dari tahun ke tahun. Karakteristik $\mathrm{Pb}-210$ excess lapisan sedimennya dipengaruhi oleh sumber sedimen potensial yang berasal dari erosi lembaran dari lahan, erosi parit dari lapisan sub-soil, aktivitas pencucian galian pasir, maupun erosi river bank. Kombinasi berbagai sumber potensial tersebut yang akan mewarnai profil aktivitas $\mathrm{Pb}-210$ excess, dimana sedimen yang mengandung $\mathrm{Pb}-210$ excess tinggi berasal dari lahan pertanian sedangkan sumber lainnya boleh jadi hanya sedikit atau bahkan tidak ada Pb-210 excess. Dari ketiga cara mendapatkan profil $\mathrm{Pb}-210$ excess, cara pertama (tiap perlapisan) dan cara ketiga (normalisasi C) memberikan hasil yang hampir sama, terutama untuk sedimen dataran banjir lokasi 2. Data ini sebagai salah satu bukti bahwa baik $\mathrm{Pb}-210$ excess maupun soil organik karbon terikat bersama-sama cukup kuat pada partikel halus sedimen. Ada kecenderungan kenaikan laju sedimentasi yang signifikan; di lokasi 1 laju sedimentasi berkisar 1,028 cm/tahun dari tahun 19681987 naik menjadi sekitar 2,83 cm/tahun dari tahun 1987-2016 (28,95 tahun). Demikian juga kenaikan laju sedimentasi di lokasi 2 yang lebih ke arah hilir letaknya, dari kisaran 0,676 cm/tahun dari kurun waktu tahun 1950-1993 menjadi kisaran 3,231 cm/tahun dari kurun waktu tahun 1993-2016 (23 tahun).

\section{UCAPAN TERIMA KASIH}

Penulis mengucapkan banyak terima kasih kepada seluruh staf terkait di kelompok Sedimentologi-PAIR, diantaranya Bapak Darman dan Bapak Marwadi yang telah membantu dalam pengambilan sampel dan preparasi serta penyiapan peralatan lapangan lain. Penulis juga mengucapkan banyak terima kasih kepada para reviewer dengan segala koreksi dan masukannya sehingga karya tulis ini dapat dipublikasikan.

\section{DAFTAR PUSTAKA}

[1] BPDAS, Pengelolaan DAS Ciujung Terpadu Tahun 2010. BP DAS Ciliwung-Citarum 2010.

[2] S. Mares and M. Tvrdý, Introduction to Applied Geophysics. Prague: Charles Univ., D. Radel Publishing Company, 1984.

[3] B. Aliyanta, N. Suhartini, dan B. Pratikno, "Studi Awal Penentuan Sumber Sedimen DAS Cisadane Hulu dengan Radionuklida Alam", Jurnal Ilmiah Aplikasi Isotop dan Radiasi, 11, 39-49, 2015.

[4] V. Putyrskaya, E. Klemt, S. Rollin, M. Astner, and H. Sahli, "Dating of Sediment from Four Swiss Prealpine Lakes with Pb-210 Determined by Gamma-Spectrometry", Journal of Environmental Radioactivity, 145, 78-94, 2015.

[5] B. Aliyanta, N. Suhartini, dan T. Hutabarat, "Laporan Teknis Litbang 2015", Jakarta Selatan : PAIR-BATAN, 2015.

[6] V. Golosov and D. E. Walling, "Using Fallout Radionuclides To Investigate Recent Overbank Sedimentation Rates On River Floodplain: An Overview", New Orleans, Louisiana : IAHS Publ. 367, 2015.

[7] P. Du and D.E. Walling, "Using Pb-210 Measurements to Estimate Sedimentation Rates on River Floodplains.", Journal of Environment Radioactivity, 103, 59-75., 2012.

[8] G. Matisoff, "Pb-210 as a Tracer of Soil Erosion, Sediment Source Area Identification and Particle Trasport in the Terrestrial Environment", Journal of Environmental Radioactivity, 138 , 343-354, 2014.

[9] C. E. Renshaw, K. Abengoza, F. J. Magilligan, W. B. Dade, and J. D. Landis, "Impact of Flow Regulation on Near-Channel Flooplain Sedimentation", Geomorphology, 205, 120-127, 2014.

[10] L. Mabit, M. Benmansour, and D. E. Walling, "Comparative Advantages and Limitations of Fallout Radionuclides Cs-137, Pb-210, and Be-7 to Assess Soil Erosion and Sedimentation", Journal of Environmental Radioactivity, 99, 1799-1807, 2008.

[11] Y. H. Yang, B. X. Yan, and H. Zhu, "Estimating Soil Erosion in Northeast China Using Cs-137 and Pb-210 ex.", Pedosphere, 21-6, 706-711, 2011. 
[12] M. Gibbs, "Protocol on the Use of the CSSI Technique to Identify and Apportion Soil Sources from Land Use", Prepared for Joint FAO/IAEA Division Technique in Food and Agriculture, NIWA, Taihori Nukuragi, New Zealand, Revised 2013.

[13] T. T. Mengistu, Y. Onda, H. Kato, Y. Wakiyama, S. Mizugaki, and S. Hiramatsu, "The Relationship of Soil Organic Carbon to $\mathrm{Pb}-210$ excess dan Cs137 during Surface Soil Erosion in a Hillslope
Forested Enviroment", Geoderma, 192 , 59-67, 2013.

[14] B. Aliyanta, "Kajian Komparatif Parameter Kualitas Tanah di Beberapa Tataguna Lahan sub-DAS Cisadane Hulu dengan Pb-210 excess dan Cs-137", Jurnal Ilmiah APLIKASI ISOTOP DAN RADIASI, 11, 113-124, 2015.

[15] M. Strok, B. Modis, B. Petrinec, and Z. Franic, "Correcting for Potential Rn-222 Loss in Pb-210 Dating of Sediments from the South Adriatic Pit", Quaternary Geochronology, 18, 93-98, 2013. 